\title{
PENGGUNAAN TWIN BLOCK PADA PERAWATAN MALOKLUSI KELAS II ANGLE ANAK-ANAK
}

\author{
Risti Saptarini, Meirina Gartika, Jaköbus Runkat \\ Bagian Ilmu Kesehatan Gigi Anak Fakultas Kedokteran Gigi Universitas Padjadjaran
}

Risti Saptarini, Meirina Gartika, Jakobus Runkat. Penggunaan Twin Block pada Perawatan Maloklusi kelas II Angle Anak-anak. Indonesian Journal of Dentistry 2005; 12 (2): 50-54.

\begin{abstract}
A 12 years old female presented with class II division I malocclusion with skeletal disorder (ANB $6^{\circ}$ ), deep bite, posterior crossbite 26 , protrusive of anterior maxillary teeth, maxillary constriction, retrognatic of mandible and mild crowding of upper and lower jaws. The treatment of choice was twin block appliance for modifying the jaw development, and then followed by fixed orthodontics. After eight months, the progression of treatment was a better facial profile.
\end{abstract}

Key words: malocclusion, twin block appliance, orthodontic treatment.

\section{Pendahuluan}

Maloklusi kelas II berdasarkan klasifikasi Angle adalah hubungan gigi molar pertama rahang bawah yang berada di sebelah distal gigi molar rahang atas pada saat beroklusi. Kelainan ini disebut juga distoklusi. Angle membagi kelainan ini menjadi dua divisi, yaitu divisi 1 dan $2 .{ }^{1}$

Penelitian epidemiologi menunjukkan prevalensi maloklusi kelas II mengenai $20 \%$ populasi di Amerika Serikat. Hasil yang hampir sama ditunjukkan pula oleh penelitian yang dilakukan di Eropa. Prevalensi maloklusi kelas II pada populasi orang Afrika asli adalah $1-10 \%$, sedang di Arab (Timur Tengah) prevalensi kelainan ini berkisar $10-$ $15 \%$. Survei yang dilakukan di Asia Timur sampai Tenggara menunjukkan prevalensi maloklusi kelas II yang hampir sama dengan di Timur Tengah. ${ }^{2}$

Maloklusi kelas II dapat bersifat dental dan/atau skeletal. Etiologi maloklusi kelas II dental adalah protrusi gigi-gigi rahang atas dan adanya gerakan ke mesial gigi molar pertama tetap rahang atas. Etiologi maloklusi kelas II skeletal adalah adanya pertumbuhan mandibula yang kurang atau pertumbuhan maksila yang berlebih.

Terdapat 3 alternatif penanganan maloklusi kelas II skeletal, yaitu mengarahkan arah pertumbuhan tulang (growth modification), perawatan kamuflase (dental camouflage), dan pembedahan ortognatik (orthognathic surgery). Anak-anak yang sedang dalam masa tumbuh kembang dapat menerima ketiga macam perawatan maloklusi kelas II skeletal ini, sedangkan orang dewasa hanya dapat dilakukan perawatan kamuflase atau bedah ortognatik. ${ }^{2}$

Penanganan maloklusi kelas II skeletal pada anak yang sedang dalam masa pertumbuhan adalah dengan mengarahkan pertumbuhan rahang. Tujuan utama mengarahkan pertumbuhan rahang adalah merubah hubungan rahang yang tidak harmonis 
dengan memanfaatkan masa pertumbuhan wajah pada anak sehingga dicapai perubahan ukuran dan posisi rahang yang diinginkan. Terdapat 3 macam alat ortodontik yang digunakan untuk mengarahkan pertumbuhan rahang, yaitu alat-alat ekstraoral (extraoral force alppliances), alat-alat fungsional (functional appliances), dan traksi elastik antar lengkung rahang (interarch elastic traction). Alat ortodontik yang digunakan untuk mengarahkan pertumbuhan rahang disebut alat ortopedik. ${ }^{2}$

Makalah ini merupakan laporan kasus penanganan pasien anak umur 12 tahun dengan kelainan maloklusi kelas II skeletal yang datang ke klinik Ilmu Kesehatan Gigi Anak FKG Unpad dengan menggunakan alat fungsional twin block. Prinsip kerja alat fungsional adalah merubah posisi mandibula menjadi hubungan oklusi kelas I dengan tujuan agar muscle engram dari otot-otot orofasial terkondisikan secara fisiologis, sehingga arah pertumbuhan rahang menjadi seimbang dan harmonis. ${ }^{2,3}$

\section{Tinjauan Pustaka}

Pierre Robin pada tahun 1902 pertama kali mengembangkan alat fungsional aktivator atau monoblock. Aktivator banyak digunakan di Eropa. Hasil penelitian mengenai aktivator menunjukkan koreksi maloklusi kelas II skeletal lebih mengarah kepada perubahan dentoalveolar dibandingkan terhadap struktur skeletalnya. Balters, tahun 1950 memperkenalkan bionator untuk meningkatkan kenyamanan pasien sehingga pemakaian alat seharihari dapat lebih lama. Bionator diciptakan lebih tipis dibandingkan aktivator. Rolf Frankel, tahun 1966 memperkenalkan alat koreksi fungsional (functional corrector atau functional regulator). Alat ini diciptakan sangat unik. Prinsip kerja alat ini lebih banyak didukung oleh struktur vestibulum dibandingkan oleh gigi dan merupakan satu-satunya alat fungsional yang didukung -jaringan lunak (tissue-borne). Alat-alat fungsional tersebut mempunyai beberapa kelemahan, yaitu memerlukan kooperatif pasien, ketebalan alat yang membuat tidak nyaman saat dipakai, mengganggu fungsi bicara, serta tidak dapat memperbaiki malposisi gigi. ${ }^{2,4}$

Keterbatasan alat fungsional ini dapat diperbaiki dengan diperkenalkannya alat twin block oleh William Clark tahun 1977. Twin block terdiri dari 2 plat akrilik yang dipasang di rahang atas dan bawah. Plat rahang atas dan rahang bawah bertemu pada regio premolar dengan kemiringan bidang $70^{\circ}$. Alat ini dapat dipakai selama 24 jam tanpa mengganggu fungsi bicara dan pengunyahan. Twin block merupakan satu-satunya alat fungsional yang dapat dipakai selama 24 jam, sehingga diharapkan terjadi adaptasi terhadap perubahan yang cepat dari tulang, gigi dan neuromuskuler., ${ }^{2,5}$

Indikasi alat fungsional adalah pada anak yang sedang dalam pertumbuhan, terutama sebelum mencapai peak pubertal growth spurt, mandibula yang retrognatik, arah pertumbuhan yang normal atau horisontal, sudut bidang mandibula yang normal atau kecil-dan pasien yang kooperatif.

Bidang inklinasi oklusal merupakan mekanisme fungsional dasar gigi geligi. Mekanisme bidang inklinasi berperan penting dalam hubungan antar bonjol (cusp) saat gigi mencapai bidang oklusi. Keseimbangan fungsional ini terbentuk oleh adanya kontrol neurologis terhadap rangsang taktil yang berulang. Tekanan oklusal yang disalurkan pada gigi geligi menghasilkan stimulus proprioceptif yang konstan. Stimulus ini mempengaruhi kecepatan pertumbuhan dan struktur tulang pendukung. ${ }^{5}$

Maloklusi biasanya berkaitan dengan adanya perbedaan lebar lengkung rahang. Hal ini dapat disebabkan oleh struktur tulang pendukung dan faktor jaringan lunak. Akibatnya terjadi panduan oklusi yang salah dan fungsi oklusal yang buruk. Mekanisme umpan balik sensoris proprioceptif dapat menjadi stimulus fungsional atau penghambat pertumbuhan tulang mandibula yang optimal. Kontak bonjol (cusp) yang salah seperti distoklusi pada kasus maloklusi II menunjukkan adanya hambatan untuk pertumbuhan mandibula yang optimal ke arah depan. ${ }^{5}$

Alat twin block mengubah bidang inklinasi oklusal dan memanfaatkan tekanan oklusal untuk memperbaiki maloklusi. Posisi mandibula dipandu untuk maju ke depan oleh bidang inklinasi oklusal ini. Alat twin block diciptakan untuk dipakai selama 24 jam sehingga dapat memanfaatkan semua daya fungsional yang mengenai gigi termasuk tekanan pengunyahan. Alat ini terdiri dari 2 plat akrilik yang dipasang di rahang atas dan bawah dan saling mengunci dengan kemiringan bidang $70^{\circ}$ pada saat rahang menutup. Disain alat untuk mengkoreksi kelainan maloklusi kelas. II adalah bidang miring dibuat di sebelah mesial gigi molar pertama tetap rahang atas dan rahang bawah. Plat rahang atas menutupi permukaan oklusal gigi-gigi molar rahang atas, sedangkan plat rahang bawah menutupi permukaan oklusal gigi-gigi premolar. Cangkolan alat yang digunakan biasanya cangkolan delta atau bola. $^{5}$ 
Sebelum pembuatan alat twin block di laboratorium, yang terpenting adalah mendapatkan pencatatan gigitan pasien. Alat yang digunakan untuk pencatatan gigitan ini adalah Exatobite atau Project Bite Gauge. Pasien yang mempunyai overjet sebesar $10, \mathrm{~mm}$ dapat langsung dikoreksi pada aktivasi awal, yaitu dengan cara gigitan pasien dibuat edge to edge dengan jarak interinsisal $2 \mathrm{~mm}$. Overjet yang lebih besar dari $10 \mathrm{~mm}$ harus dilakukan dalam 2 tahap perawatan. ${ }^{5}$

Fase perawatan dengan alat fungsional twin block memperbaiki relasi antero-posterior dan dimensi vertikal ${ }^{5}$ :

(1) Fase aktif, yaitu merubah hubungan molar kelas II menjadi kelas I dengan dipandu oleh bidang inklinasi oklusal sehingga relasi mandibula dan maksila berada pada posisi yang benar. Lama perawatan $6-9$ bulan. Hasil yang dicapai pengurangan overjet, relasi gigi insisif dan relasi raharg yang normal.

(2) Fase support, yaitu mempertahankan dimensi vertikal dengan menggunakan alat Hawley dengan bidang inklinasi anterior di rahang atas. Lama perawatan 3-6 bulan

(3) Fase retensi, selama 9 bulan serta lamanya pemakaian alat dikurangi apabila telah dicapai posisi yang stabil. Alat twin block ini lebih fleksibel, yaitu perawatannya dapat dikombinasi dengan pemakaian alat cekat pada fase finishing dan detailing.

\section{Penatalaksanaan kasus}

Seorang anak perempuan umur 12 tahun datang ke klinik spesilis kedokteran gigi anak RSGM FKG Unpad, dengan keluhan gigi depan rahang atas maju ke depan sehingga pasien merasa malu dan ingin dirawat.

Pemeriksaan intraoral, gigi permanen pasien telah erupsi lengkap, kondisi kebersihan mulut baik dan bebas karies. Pasien mempunyai overjet $8 \mathrm{~mm}$, terdapat gigi berjejal ringan di rahang atas dan bawah, cross bite posterior pada gigi 26 dan deep overbite (gigitan dalam). Hubungan molar kiri dan kanan menunjukkan hubungan kelas II. Berdasarkan klasifikasi Angle adalah kelas II divisi I.

Analisis sefalometri menunjukkan adanya kelainan skeletal kelas II dengan sudut ANB $6^{\circ}$. Rahang atas normal (SNA $82^{\circ}$ ) dan rahang bawah retrognati $\left(\mathrm{SNB} 76^{\circ}\right)$. Sudut I - NA $33^{\circ}$ berarti gigi insisif rahang atas protrusif. Sudut Go.Gn - SN $27^{\circ}$ yang berarti potensi pertumbuhan mandibula dan wajah normal. Sudut sumbu Y - FHP $65^{\circ}$ berarti normal.
Hasil analisis ruang pada model studi terjadi kontraksi pada rahang atas, terdapat perbedaan panjang lengkung rahang atas sebesar $2 \mathrm{~mm}$. Rencana perawatan yang dilakukan adalah memperbaiki relasi oklusi skeletal kelas II, deep overbite dan kontraksi rahang atas dengan menggunakan alat fungsional twin block yang dimodifikasi. Alasan penggunaan alat fungsional twin block ini karena pasien masih dalam masa pertumbuhan dan perkembangan. Kelainannya diakibatkan oleh mandibula yang retrognati, sedangkan maksila normal serta pasien kooperatif.

Perawatan dimulai pada tanggal 20 Juni 2004 dengan dilakukan pencetakan rahang atas dan rahang bawah, serta pengambilan foto panoramik, sefalometri dan transkranial. Setelah dilakukan analisis model dan sefalometri kemudian dilakukan pencatatan gigitan.

Sebelum dilakukan pencatatan gigitan, pasien dilatih untuk memajukan rahangnya ke depan sampai mencapai posisi edge to edge, dicapai hubungan molar kelas I dan terdapat jarak inter insisal sebesar $2 \mathrm{~mm}$. Pencatatan gigitan pasien menggunakan lilin merah dengan ketebalan $5 \mathrm{~mm}$. Teraan gigitan lilin merah dimasukan ke dalam air es, kemudian dipindahkan pada model dan difiksir. Alat twin block dibuat di laboratorium.

Pemasangan alat dilakukan pada tanggal $1 \mathrm{Juli}$ 2004. Kontrol dilakukan 2 minggu sekali untuk aktivasi alat. Cara mengaktivasi alat twin block untuk merawat deep overbite adalah dengan menggerinda tanggul gigitan rahang atas pada bidang oklusal sebesar $1-2 \mathrm{~mm}$. Pada saat penggerindaan harus diperhatikan tidak boleh lebih dari $1-2 \mathrm{~mm}$ untuk mencegah lidah menempati ruang kosong dan untuk mempercepat erupsi gigi molar rahang bawah. Bidang miring tidak boleh dikurangi sehingga dukungan oklusal fungsional yang adekuat tetap ada sampai diperolah 3 titik kontak oklusal. Aktivasi sekrup ekspansi sebesar 1/4 putaran setiap 2 minggu untuk memperbaiki crossbite gigi 26. Fase aktif ini dilakukan selama 6 9 bulan, kemudian akan dilanjutkan dengan fase support dan retensi. 


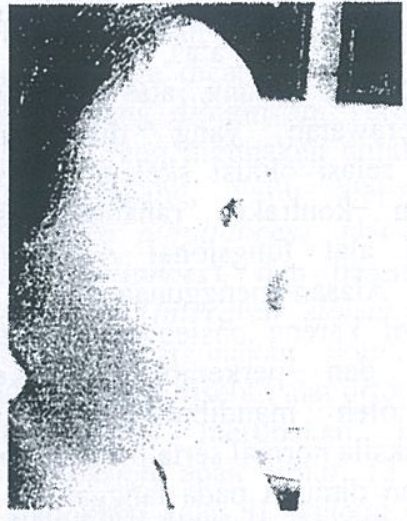

Gambar 1. Foto profil sebelum perawatan

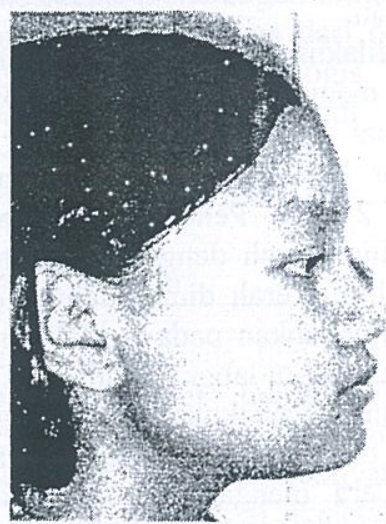

Gambar 2. Foto profil setelah 8 bulan perawatan
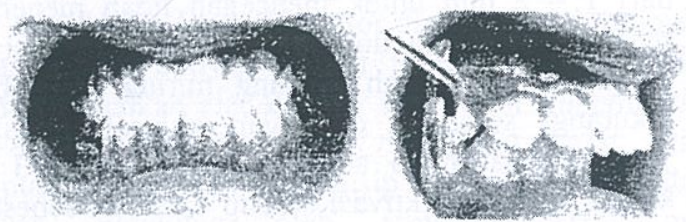

Gambar 3. Intraoral sebelum perawatan
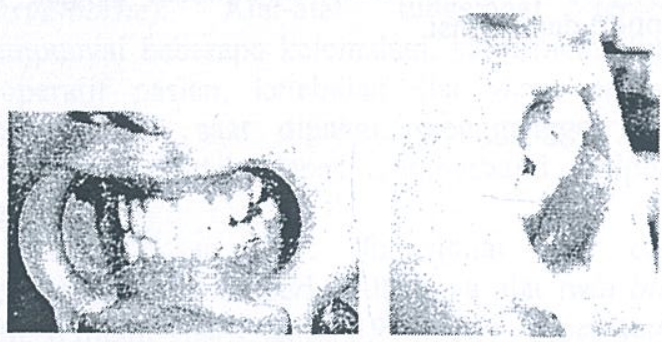

Gambar 4. Intraoral setelah 8 bulan perawatan

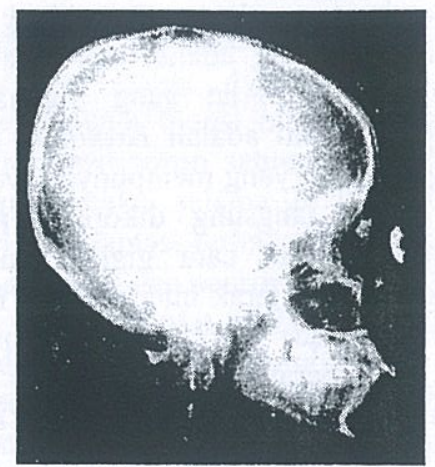

Gambar 5. Sefalometri sebelum perawatan

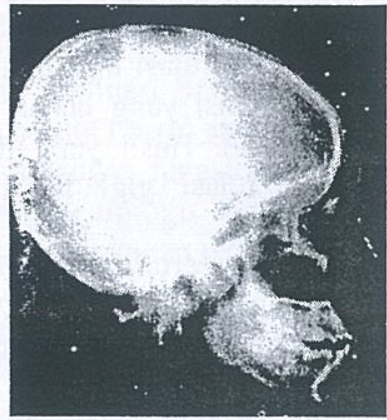

Gambar 6 . Sefalometri setelah 8 bulan perawatan

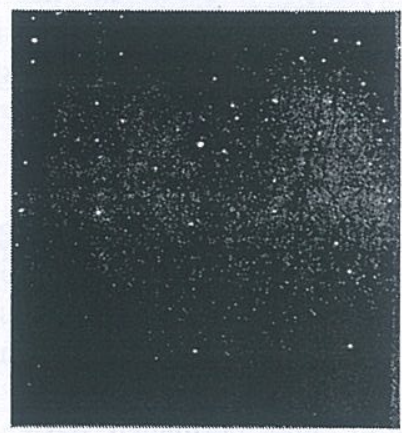

Gambar 7. Tracing sefalometri sebelum perawatan

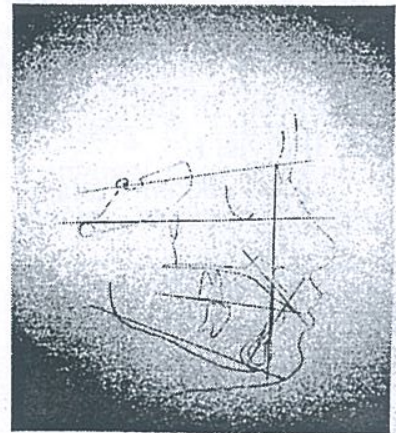

Gambar 8. Tracing sefalometri setelah 8 bulan perawatan 


\section{Pembahasan}

Tujuan perawatan kasus ini adalah memperbaiki hubungan molar kelas II Angle, deep overbite, kontraksi rahang atas dan memperbaiki keseimbangan profil wajah. Keberhasilan penanganan maloklusi kelas II skeletal tergantung pada koreksi kelainan dalam arah antero-posterior, vertikal dan transversal. ${ }^{6}$. Pada kasus ini pasien masih dalam masa pertumbuhan, kelainan diakibatkan oleh mandibula yang retrognatik, maksila normal, dan pasien sangat kooperatif sehingga dipilih perawatan menggunakan alat fungsional twin block.

Hasil perawatan menunjukkan alat twin block paling efektif untuk memperbaiki kelainan dalam arah antero-posterior dan vertikal dibandingkan alat fungsional lain. ${ }^{7.8}$ Alat ini dipakai selama 24 jam dan tidak mengganggu fungsi bicara serta pengunyahan, sehingga dapat meningkatkan koopertif pasien.

Koreksi hubungan molar kelas II menjadi kelas I dengan cara merubah posisi mandibula. Mandibula diturunkan dan dimajukan sampai dicapai hubungan molar kelas I. Secara teori, penarikan kepala kondilus menjauhi fosa glenoidalis dapat mengurangi tekanan terhadap kartilago tulang yang sedang aktif berkembang, serta terjadi perubahan tekanan otot terhadap kepala kondilus. Hal ini akan meningkatkan jumlah sel endochondral untuk pertumbuhan. ${ }^{2}$

Koreksi deep overbite diperoleh dengan cara penggerindaan yang selektif pada bagian oklusodistal tanggul gigitan rahang atas. Tujuan penggerindaan adalah untuk merangsang erupsi gigi molar rahang bawah sehingga dapat meningkatkan dimensi vertikal. Peningkatan dimensi vertikal akan menambah tinggi wajah bagian bawah dan kesimbangan profil wajah. Perubahan profil wajah terlihat langsung setelah alat twin block dipasang di mulut pasien. Perubahan otot-otot kraniofasial yang cepat terjadi sebagai respon terhadap perubahan fungsi otot karena pemakaian alat fungsional sepanjang waktu. Perubahan keseimbangan otot yang merubah profil wajah secara signifikan akan terlihat dalam 2-3 minggu setelah pemasangan alat. Pemakaian twin block dapat mengembalikan lip seal tanpa harus melakukan latihan untuk otot bibir. ${ }^{2}$

Perawatan kasus ini telah berjalan selama 8 bulan, pasien kontrol setiap 2 minggu sekali untuk aktivasi alat. Keluhan pasien hanya pada bulan pertama setelah pemasangan alat, yaitu terasa pegal pada daerah sendi rahang. Hasil perawatan setelah 8 bulan adalah pengurangan pada konveksitas profil wajah. Hal ini menunjukkan bahwa terjadi perubahan posisi kondilus, pengurangan overjet serta relasi rahang menjadi kelas I (ANB $3^{0}$ ). Rencana perawatan selanjutnya setelah fase aktif selesai adalah pemasangan alat cekat dan retensi.

\section{Daftar Pustaka}

1. Proffit WR. Contemporary Orthodonthics. St Louis Mosby 2000: 3, 475.

2. Bishara SEW. Texbook of Orthodonthics. Philadelphia WB. Saunders Co 2001: 343-51.

3. Okeson JP. Temporomandibular Disorders and Occlusion 4ed. St Louis Mosby 1998: 171-2.

4. Cameron AC, Widner RP. Handbook of Pediatric Dentistry 2nd. London Mosby 2003: 315-21.

5. Clark WJ. Twin Block Functional Therapy Applicatians in Dentofacial. Orthodonthics. London Mosby-Wolfe 1995: 9-23.

6. Selwyn BJ. Rational of Treatment for Class II Division 2 Malocclusion. Brit J Orthod 1991; (18): 173-81.

7. Toth LR and McNamara JA. Treatment Effects by Twin Block Appliance and The FR-2 Appliance of Frankel Compared with An Untreated Class II Sample. Am J Orthod and Dentofacial Orth-paedics 1999; (116): 597-609.

8. Illing H. A Prospective Evaluation of Bass, Bionator and Twinblock Appliances. Part 1 The Hard Tissue. Eur J Orthod 1988; (20): 501-16. 